\title{
PROGRAM KEMITRAAN MASYARAKAT STIMULUS UMKM MARNING DI DESA MASDA MAKMUR
}

\author{
Rina Ari Rohmah ${ }^{1)}$, Purwantoro ${ }^{2)}$, Erni Rouza ${ }^{3)}$ \\ Universitas Pasir Pengaraian \\ ${ }^{1}$ Email: purwan78@gmail.com \\ ${ }^{2}$ Email: rinaarirohmah@gmail.com \\ ${ }^{3}$ Email: ernirouzait@gmail.com
}

\begin{abstract}
The Stimulus Community Partnership Program ( PKMS ) was implemented at the UMKM Marning Mbok Jas. In this stimulant community partnership program there are three efforts to solve the problems faced by partners, namely the first increase in the ability of science and technology in the production system, this effort is made to increase production productivity, optimize production and improve hygienic marning quality. The second effort is to increase the variant of the production of processed corn and corn marning; it aims to increase the variant of corn marning products, namely to increase the variant of corn marning flavor. By creating a third effort which is to change the marketing strategy by creating a taste that consumers like and a consistent taste, making brochures, and labeling it to look attractive and other marketing activities and marketing in the marketplace.
\end{abstract}

Keywords: Marning Mbok Jas, Rokan Hulu, Varian

\section{ANALISIS SITUASI}

Pada saat ini sektor industri pengolahan merupakan salah satu penyumbang dalam memantapkan perekonomian di Indonesia. Keberadaan sektor industri pengolahan merupakan salah satu motor penggerak yang penting bagi pertumbuhan ekonomi Indonesia. Industri pengolahan pangan merupakan industri yang bergerak dalam pengolahan hasil pertanian, baik nabati maupun hewani menjadi produk pangan olahan. Menurut Soleh (2003) pengembangan industri pengolahan pangan didukung oleh sumber daya alam pertanian, baik nabati mapun hewani yang mampu menghasilkan berbagai produksi olahan yang dapat dibuat dan dikembangkan dari sumber daya alam lokal. Saat ini Indonesia memiliki banyak produk pangan yang diangkat dari jenis pangan lokal dan diolah secara tradisional. Dengan berkembangnya produk lokal maka jumlah dan jenis produk pangan menjadi semakin banyak jumlahnya.

Data dari BPS juga menunjukkan pertumbuhan produksi industri (year on year) triwulan 12013 UKM mengalami kenaikan di industri makanan sebesar $10,76 \%$ dan industri minuman $9,41 \%$. Ini merupakan indikator bahwa industri makanan dan minuman yang banyak dikerjakan UKM memiliki potensi besar untuk dikembangkan. Namun masalah rendahnya produktivitas UKM selama ini masih terjadi. Organisasi yang kurang profesional, penguasaan teknologi dan pemasaran yang lemah, serta rendahnya kualitas kewirausahaan dari para pelaku usaha adalah beberapa kendala yang dihadapi UKM. Data ini membuktikan potensi UKM sebagai penggerak perekonomian masyarakat sangat besar.(presidenri.go.id, 2016)

Kabupaten Rokan Hulu mempunyai Usaha Kecil Marning Jagung Mbok Jas khususnya pangan. Data dari Dinas Perindustrian Koperasi dan UKM Kabupaten Rokan Hulu (2017) menunjukkan bahwa industri kecil sebanyak 700 industri dimana keberadaanya harus dikembangkan lagi karena dapat menciptakan lapangan kerja bagi masyarakat. Kenyataannya, masih ada 
kendala yang sering muncul diantaranya kurangnya modal dan kurangnya bimbingan teknis.

Dalam pengembangan Usaha Kecil Marning Jagung Mbok Jas diperlukan analisis usaha yang nantinya dapat diketahui penerimaan, biaya dan pendapatan Usaha Kecil Marning Jagung Mbok Jas sehingga menunjukkan prospek layak dikembangkan. Dalam pengembangan Usaha Kecil Marning Jagung Mbok Jas bila strategi pengembangan dilakukan dengan tepat maka diharapkan dapat mengoptimalkan pemanfaatan potensi sumberdaya dan peluang usaha industri makanan dalam rangka mendukung pembangunan dan peningkatan taraf hidup pengusaha dan para stakeholders lainnya.

Desa Masda Makmur merupakan salah satu desa di Kecamatan Rambah Samo Kabupaten Rokan Hulu, sebagian besar penduduknya berasal dari etnis jawa, di desa ini terdapat Usaha Kecil Marning Jagung Mbok Jas (rumah tangga) pembuatan Marning Jagung sebanyak 1 lokasi usaha dengan 3 orang tenaga kerja. Hasil usaha ini dimanfaatkan untuk kepentingan konsumsi sebagai salah satu sumber karbohidrat bagi sebagian besar penduduk di desa ini. Jika dibandingkan dengan Usaha Kecil Marning Jagung yang beredar di pasaran maka pengembangan Usaha Kecil Marning Jagung Mbok Jas sangat diperlukan karena terlihat bahwa terjadi penyerapan tenaga kerja masih dibawah Usaha Kecil Marning Jagung dipasaran, mengingat bahan baku yang digunakan sama.

\begin{tabular}{llrr}
\multicolumn{2}{c}{ Prospek pemasaran marning } \\
jagung cukup baik sehingga harus \\
didukung oleh produksi yang terus \\
kontinyu. Kualitas marning jagung yang \\
dihasilkan harus bagus & sehingga \\
konsumen lebih tertarik & untuk \\
mengkonsumsi. Persaing & yang \\
dihadapi hanya datang & dari \\
pengusaha & sejenis & sekitar & Desa
\end{tabular}

Rambah Utama. Kenyataanya, masih ada kendala yang sering muncul dalam industri kecil marning jagung yaitu promosi yang dilakukan selama ini masih mengandalkan media mulut ke mulut dan door to door. Hal ini menyebabkan produk yang dihasilkan kurang dikenal oleh masyarakat secara luas. Selain itu, masih kurangnya peran pemerintah daerah dalam rangka mengembangan industri kecil marning jagung di Kecamatan Rambah Kabupaten Rokan Hulu.

Berdasarkan survey awal yang telah dilakukan kepada Pengusaha Marning Jagung Mbok Jas yang ada di Desa Masda Makmur ditemukan akar permasalahan yang mereka hadapi dalam menjalankan usahanya adalah :

1. Ketergantungan terhadap jagung di daerah Rokan Hulu masih tergantung dari daerah lain. Hal ini terjadi karena kualitas jagung dan kuantitas lokal masih rendah jika dibandingkan dengan jagung daerah lain masih rendah sehingga jika digunakan jagung daerah lokal berpengaruh terhadap hasil olahan yaitu menghasilkan marning jagung yang keras.

2. Teknologi proses produksi yang belum efisien. Teknologi yang dipakai saat ini masih tradisional, contohnya mereka hanya menggunakan sinar matahari untuk proses pengeringan setelah perebusan jagung.

3. Teknologi proses pengemasan yang belum baik, yaitu saat ini masih di pakai plastik biasa

4. SDM yang masih rendah. Kualitas sumber daya manusia masih rendah karena masih minim pengetahuan serta hanya mengandalkan perkiraan pada proses pelaksanaan produksi.

5. Permodalan yang terbatas. Permasalahan permodalan merupakan permasalahan klasik yang selalu menghambat jalannya sebuah usaha. Para pengusaha membutuhkan pinjaman modal yang dapat 
membantu mereka untuk menghidupi usahanya.

6. Diversifikasi produk yang tidak optimal. Keterbatasan jumlah tenaga kerja dan pengetahuan tentang strategi pemasaran membuat para pengusaha kecil tidak mampu bersaing dengan kompetitor. Pengusaha marning jagung mbok jas juga bekerja sebagai penjual sehingga mengurangi waktu produksi dan waktu penjualan. Karena sebelum menjual mereka harus membuat marning jagung terlebih dahulu

maka melalui Program Kemitraan
Masyarakat Stimulan ini akan dilakukan tiga upaya utama sebagai solusi. Upaya pertama adalah peningkatan kapasitas ipteks dalam sistem produksi, upaya ini bertujuan untuk meningkatkan produktivitas produksi, meningkatkan kualitas pengemasan, meningkatkan kualitas marning jagung, dan peningkatan kualitas lingkungan kerja yang lebih higienis. Upaya kedua adalah peningkatan produksi olahan marning jagung, hal ini dilakukan untuk menambah varian produk hasil dari olahan marning jagung yaitu varian produk yang akan ditambahkan adalah marning jagung rasa keju, marning jagung rasa sambalado, marning jagung rasa original dan marning jagung rasa pedas. Upaya yang ketiga adalah melakukan perubahan strategi pemasaran dengan menciptakan rasa yang disukai konsumen dan rasa yang konsisten, menjual di marketplace dan sosial media, membuat brosur/flyer, dan memberi label agar kelihatan menarik dan kegiatan pemasaran yang lain.

\section{METODE PELAKSANAAN}

Metode pelaksanaan yang dilakukan agar solusi yang ditawarkan dapat disalurkan dengan baik kepada mitra sesuai yang diharapkan upaya yang dilakukan adalah dengan memberikan penyuluhan dan pelatihan kepada Mitra Usaha Marning Jagung Mbok Jas.

Tahapan-tahapan pelaksanaan kegiatan pengabdian ini antara lain:

1. Penyuluhan

Dalam kegiatan penyuluhan ini, mitra akan dibekali dengan materi penyuluhan tentang cara mengembangkan usaha Usaha Kecil Marning Jagung Mbok Jas dengan melakukan peningkatan kapasitas iptek dalam sistem produksi, peningkatan produksi olahan jagung dan marning jagung, serta perubahan strategi pemasaran.

2. Pelatihan

Pelatihan yang diberikan adalah dalam bentuk demonstrasi secara langsung mengenai cara pengembangan usaha Usaha Kecil Marning Jagung Mbok Jas dengan pembuatan produk baru dari olahan jagung yaitu pelatihan pembuatan varian rasa marning jagung dan pelatihan pembuatan susu jagung.

3. Uji Coba

Uji coba dilakukan untuk melihat capaian hasil kegiatan penyuluhan dan pelatihan. Uji coba pembuatan produk akan dilakukan dalam skala kecil, dan hasil dari uji coba akan melalui proses pengujian laboratorium untuk membuktikan kandungan gizi produk susu jagung. Tujuan dari pengujian ini adalah agar produk yang dihasilkan memenuhi standard mutu gizi sehingga tidak meragukan konsumen. Setelah beberapa uji coba dilakukan dan didapat hasil yang sesuai dengan yang diharapkan maka dilanjutkan dengan proses produksi.

4. Rancangan Monitoring dan Evaluasi Monitoring dan evaluasi dilakukan selam berjalannya program. Tujuan dari pelaksanaan monitoring dan evaluasi adalah untuk mengetahui sejauh mana pemahaman mitra terhadap aplikasi 
ipteks, pengetahuan pengembangan produksi olahan kedelai dan pengetahuan tentang sistem pemasaran yang telah diberikan.

5. Partisipasi Mitra

Pada saat pelaksanan peran mitra adalah mengikuti penyuluhan, pelatihan, dan ujicoba yang akan diberikan oleh tim pengusul dan ikut serta dalam pengambilan keputusan akhir untuk menerapkan solusi yang ditawarkan. Mitra bertanggung jawab terhadap seluruh pekerja di dalam lingkungan usahanya yang dibantu oleh tim pengusul dan mahasiswa.

\section{HASIL DAN PEMBAHASAN}

Berdasarkan tahapan pelaksanaan kegiatan pengabdian masyarakat yang telah disusun dalam metodologi pelaksanaan maka dapat dijelaskan hasil yang telah dicapai sebagai berikut :

1. Peningkatan Kapasitas Ipteks dalam Sistem Produksi

a. Penggunaan Spiner pada proses penurunan kadar minyak pada marning jagung

Spinner digunakan untuk proses pengeringan marning jagung selepas di goreng, setelah dilakukan proses spiner ini kadar minyak residu pada marning jagung turun sampai $70 \%$. Spiner yang di berikan pada mitra berkapasitas sebesar $3 \mathrm{Kg}$, dilakukan kurang lebih 30 Menit dalam setiap produksi 30 KG. Proses yang optimal untuk menurunkan kadar minyak di marning jagung adalah setelah proses penggorengan apabila lebih dari itu maka akan kesulitan pada penurunan kadar minya karena minyak akan meresap ke inti marning jagung.

b. Mesin oven

Penggunaan masin oven dilakukan untuk menggantikan proses pengeringan jagung dengan matahari. Mesin oven yang digunakan menggunakan panas yang di hasilkan dari panas listrik.

c. Molen (pencampur marning jagung untuk aneka rasa)

Mesin pencampur ini digunakan untuk memudahkan pencampuran antara marning jagung dan bumbu yang telah ditentukan sebelumnya. Proses pencampuran dengan mesin ini lebih praktis serta memudahkan serta mudah dalam pengoperasian dan menghasilkan campuran yang baik dan merata. Penggerak mesin ini menggunakan motor listrik sehingga bekerja secara otomatis. Melalui proses ini higienitas dari maring jagung yang dihasilkan lebih terjamin. Kapasitas molen yang digunakan adalah $3 \mathrm{~kg}$.

d. Sealer (perekat kemasan)

Impulse sealer adalah mesin yang digunakan untuk merekatkan plastik kemasan marning jagung yang dulunya hanya menggunakan plastik biasa. Pengoperasian mesin ini menggunakan tangan dan sumber panasnya dari listrik. Mesin ini memiliki lampu indikator yang akan menyala pada saat plastik dijepitkan dan lampu akan padam secara otomatis apabila proses perekatan telah selesai.

2. Perubahan Strategi Pemasaran

a. Penyuluhan

Materi yang diberikan kepada mitra adalah memberikan pengetahuan tentang penggunaan mesin teknologi tepat guna mulai dari pengoperasian masin-masin sampai dengan perawatannya. Pada penyuluhan ini dibantu oleh 3 orang mahasiswa dari 3 prodi yang berbeda.

b. Pelatihan

Pelatihan yang diberikan kepada mitra berkaitan tentang strategi merancang bisnis UMKM, strategi pemasaran yang 
tepat untuk pengembangan UMKM dan pelatihan tentang pemanfaatan media sosial sebagai wadah pemasaran produk UMKM.

\section{Luaran yang telah dicapai}

Berdasarkan pelaksanaan kegiatan pengabdian yang telah di lakukan dapat diuraikan sebagai berikut :

1. Meningkatnya pemahaman dan ketrampilan mitra menggunakan teknologi yang sederhana, hal ini dibuktikan dengan difahaminya proses penurunan kadar minyak pada marning jagung menggunakan spinner, pemahaman penggunakan sealer, oven untuk proses produksi marning jagung.

2. Peningkatan pemahaman tentang strategi pemasaran yang tepat untuk usaha mitra.yang dibuktikannya mitra telah melaksanakan pemasaran produk marning jagungnya ke warung-warung di luar dari desa Masda Makmur.

3. Publikasi hasil kegiatan penyuluhan dan pelatihan di media online sebagai berikut link beritanya:

a. https://www.riaunet.com/berita/daera h/rohul/16323/2019/tim-dosen-uppbina-umkm-marning-mbok-jas-dimasda-makmur/

b. http://jurnalriau.com/read-3-20022019-09-05-melalui-pkms-tim-dosenupp-pacu-produktivitas-umkmmarning-mbok-jas-di-desa-masda$\underline{\text { makmur.html }}$

\section{KESIMPULAN}

Untuk menjaga keberlanjutan usaha dan memantau aktivitas bisnis mitra upaya yang telah dilaksanakan dan selanjutnya yang akan dilakukan adalah sebagai berikut :

1. Peningkatan produksi olahan jagung dan marning jagung yang akan dilakukan adalah mempraktikan hasil survei konsumen tentang upaya melakukan variasi produk marning jagung rasa-rasa. Serta melakukan diskusi dengan mitra tentang pembuatan merek dagang dan pembuatan label untuk proses pengemasan.

2. Dengan adanya kegiatan PKMS ini mahasiswa termotivasi yang kuat untuk berwirausaha dan mengabdi

3. Mitra terbantu secara teknis serta non teknis pada usahanya.

Saran pada pelaksanaan kegiatan PKMS ini adalah pemerintah daerah harus lebih proaktif dalam upaya meningkatkan UMKM karena selama ini pemerintah sedikit memberikan supportnya. Selaku pelaku usaha juga harus lebih aktif mencari informasi dan berusaha meingkatkan usaha dengan mengajak mitra-mitra usaha lainnya.

\section{UCAPAN TERIMA KASIH}

Pelaksanaan pengabdian ini terlaksana atas dukungan dari Kemenristekdikti, Universitas Pasir Pengaraian dan Mitra Usaha Marning Mbok Jas untuk itu kami selaku pelaksana mengucapkan terima kasih.

\section{DAFTAR PUSTAKA}

Soleh, M. 2003. Perbaikan Mutu dan Keamanan Pangan Produk Olahan Hasil Industri Kecil Melalui Analisa Bahaya dan Penentuan Titik Kendali. Buletin Teknologi dan Informasi Pertanian Vol 6 Januari 2003. Departemen Pertanian Badan Penelitian dan Pengembangan Pertanian (BPTP). Jawa Timur.

"Investasi UKM di Rokan Hulu" http://www.topriau.com/ekonomi/artik el/2884--intestasi-ukm-terusmeningkat-di-kabupaten-rokanhulu.html, diakses tanggal 25 agustus 2018

"Potensi UKM industri Makanan minuman" http://presidenri.go.id/beritaaktual/potensi-besar-ukm-industri- 
makanan-minuman.html, diakses tanggal 25 Agustus 2018

Jumlah UKM Rokan hulu, bps.riau.go.id, di akses tanggal 24 agustus 2018 